\title{
WHAT'S GOING ON AT THE UNIVERSITIES? HOW MUCH HAS THE RESEARCH REVEALED UNIVERSITY STUDENTS' ATTITUDES TOWARDS THE ENVIRONMENT? A CASE STUDY OF BURSA, TURKEY
}

\author{
GURBUZ, I. B. * OZKAN, G. \\ Department of Agricultural Economics, Faculty of Agriculture, Bursa Uludag University \\ Bursa, Turkey \\ *Corresponding author \\ e-mail: bulent@uludag.edu.tr; phone:+90-224-294-1591 \\ (Received 11 $1^{\text {th }}$ Jan 2019; accepted 20 $0^{\text {th }}$ Feb 2019)
}

\begin{abstract}
The aim of this research is to reveal the environmental consciousness levels of university students determine how they evaluate the society and the University at this level of consciousness and analyse the attitudes and behaviour they exert. For this purpose, a structured survey was conducted at nine faculty students at Bursa Uludag University in Turkey. Students' attitudes and behaviour were examined through their gender, family income level, parental education and professions and the field of the study variables. In this research, the questionnaire consisting of open and close-end questions was used; SPSS 23 program was used to evaluate the data. The research revealed that variables other than gender and the fathers education have a significant effect on the environmental awareness of the students. Furthermore, the students stated that universities did not take an active role in environmental protection. They attributed the lack of environmental awareness to the lack of adequate environmental protection laws and penalties. They wanted society to be more active in protecting the environment and universities to include students in environmental decisions and practices. The results show that students have inadequate environmental knowledge, therefore, display lower levels of environmental attitude and do not exert highly favourable behaviour.
\end{abstract}

Keywords: policy-making, higher education, knowledge, participation, green behaviour

\section{Introduction}

The environment can be defined as the surroundings or conditions in which a person, animal, or plant coexists and interacts. The environment is in a state of integrity and equilibrium with its living and non-living beings and is an ordered system capable of tolerating its own adversities within a certain degree. It can also be defined as all the factors that affect the lives of people and society in all aspects physically, psychologically and culturally (Baki and Cengiz, 2002). Environmental awareness is the understanding of the consequences of environmental damage and its sustainable level of use (Kollmuss and Agyeman, 2002). Environmental awareness requires a willingness to take positive actions against environmental problems.

Problems encountered in the natural and cultural environment in forms of population growth, urbanisation and improper land use have soared tremendously as a result of industrialisation and technological developments (Gayford, 2002; Mazi and Demirci, 2004; Palabiyik and Altunbas, 2004; Withgott and Brennan, 2007). As the environmental problems expanded and penetrated, the unrestrained nature of the problems has been realised. Thus, national and international efforts have been intercalated to solve them (Najam and Cleveland, 2003). Since destroying natural and cultural resources in the world is not a new phenomenon, the measures taken to protect nature are not new either. 
Nonetheless, the emergence of legal measures, the increase in environmental awareness, the systematic conservation of nature that requires the segregation of protected areas and the emergence of international organisations coincide in the nineteenth and twentieth centuries. Aforementioned developments accelerated, especially after the 1960s.

Individuals with sufficient environmental sensitivity are vital to solve environmental problems permanently. The intensity of societal perception about nature and the environment's known and unknown problems, the response and the discomfort displayed by individuals and society are the indicators of environmental awareness. The level of awareness may vary depending on a number of factors such as one's life experiences, beliefs, socioeconomic level, interactions with the natural environment and educational levels (Aydin and Cepni, 2010).

The major cause of many environmental problems is the irresponsible behaviour of the individuals and along with negative attitudes towards the environment. Therefore, it is necessary to re-establish those behavioural patterns and attitudes to eliminate the existing environmental problems, to prevent new problems and to achieve a more sustainable future (Lehman and Geller, 2004).

Environmental attitudes are the sum of all the positive and negative attitudes and thoughts of individuals, who exhibit environmentally beneficial behaviour, environmental value judgments and readiness to solve them. Environmentally friendly behaviour refers to a behaviour that harms the environment as little as possible and is influenced by various factors. The most important of these factors is environmental attitude.

While environmental attitudes are seen as strong determinants of environmentfriendly behaviour, there is a subtle difference between the two. From primary to university, students' attitudes and behaviour about the environment have been frequently examined in the literature, especially in developing countries.

Bowonder (1987) argues that environmental problems in developing countries are growing and becoming more difficult to resolve as a consequence of the combined effect of population growth, urbanisation, poverty and industrialisation. Progress is slower than developed countries (OECD Green Growth Indicators, 2017) and enforcement are mostly driven by pressure from more developed countries and international institutions such as United Nations Environmental Programme (UNEP) Global Environment Facility (GEP), Food and Agriculture Organisation of the United Nations (FAO), United Nations Educational, Scientific and Cultural Organisation (UNESCO), United Nations Industrial Development Organisation (UNIDO) and World Health Organisation (WHO) Intergovernmental Panel on Climate Change (IPCC) (Stephan and Zelli, 2009).

The population in developing countries is younger; hence young people need to shoulder the responsibility to solve them. Turkey's number of students exceeded the population of 143 countries. In the 2018-2019 academic year in Turkey, 17749876 students receive primary and secondary education in state and private schools affiliated by the Ministry of National Education. There are 7560000 students in higher education and a total of 25309876 students in Turkey (National Education Statistics, 2018). Compared to Finland and Denmark with a population of 5.5 million, Bulgaria with a population of 7 million, Azerbaijan with a population of 10 million, the Netherlands with a population of 17 million, Australia with a population of 25 million, Chile with a population of 18 million and Cameroon with a population of 25 million are behind the student population in Turkey (World Population Prospects, 2017). This explains the 
importance of research on students at varying levels of educational stages (Anonymous, 2018).

Universities bear certain responsibilities in increasing knowledge, awareness and inventing technology. They educate young generations to perform important social roles effectively; thus they have a critical role in enhancing human behaviour and promote pro-environmental behaviour (Corcoran and Wals, 2004; Frank and Meyer, 2007). In consequence, university students are regarded as decision makers, opinion shapers and the community leaders of the future in a given society (Lee, 2008; Lozano, 2006; Waas et al., 2010; Wright, 2007; Zilahy and Huisingh, 2009).

Environmental awareness, environmental conservation and sustainability have become frequently discussed issues in universities in the last twenty years. University students are equipped with more diversified and exclusive resources such as several means of media, research projects, conferences, and workshops to learn about the environment (Morigi and Krebs, 2012; Silveira and Cruz, 2012). Despite this rich resources, whether they exert sufficient environmental knowledge and awareness or reflect this knowledge to their behaviour are still questionable (Hartmann and ApaolazaIbazez, 2012; Levine and Strube, 2012; Markowitz et al., 2012).

Berberoglu and Tosunoglu (1995) and Oguz et al. (2010) reported that university students did not have sufficient awareness and participation in environmental issues. Arunkumar (2012) reported an average level of environmental awareness. Many studies have shown that the majority of university students are aware of environmental problems and believe sustainability is an important goal to be achieved. Some research confirms that students environmental knowledge influence their environmental behaviour (Huang and Shih, 2009; Thapa et al., 2005), remaining research is inconclusive. Environmental awareness and knowledge may well influence the individual's environmental behaviour. Environmental sensitivity could intensify environmental behaviour and increase participation (Sivek and Hungerford, 1990). Environmental knowledge affects behavioural intentions positively (Wang et al., 2014). As Abbas and Singh (2014) reported, a higher proportion of university students possess a high level of environmental knowledge but a low level of participation. They show interest in global problems such as climate change, acknowledge that environmental problems are serious and take a positive attitude towards it; however, the students inclined to exert minimum environmentally friendly behaviour in their everyday activities (Elder, 2003; Heyl et al., 2013; Kollmuss and Agyeman, 2002; Kormos and Gifford, 2014; Muderrisoglu and Altanlar, 2011; Schultz et al., 2005; Sharma, 2014). Hadlock and Beckwith (2002) in their study found that people did not try to understand the reasons or were not willing to participate in environmental issues that were not directly related to them. In addition, the availability of options and infrastructure, the degree of sacrifice students have to make (Arbuthnott, 2009; Kagawa, 2007; Stern, 2000) determines their environmental behaviour. Consequently, habitat or natural species become trivial to them unless there is a situation directly related or harmful. In short, there is always no linear relationship between environmental attitudes and environmentally friendly behaviour.

As stated earlier university students are more likely to access the information about the environment and achieve positions to take meaningful action and to build a more sustainable world (Sharon and Wright, 2006). For this reason, it is crucial to identify the factors affecting students' environmental behaviour. Undeniable number of research focuses on students from various countries e.g. United States (Levine and Strube, 2012; Meyer, 2016), China (Chuanhui and Hanwei, 2011), Taiwan (Chen and Tsai, 2015; Pan 
et al., 2018), Philippines (Ejem and Bello, 2013), Rwanda (Kabera, 2017), Malaysia (Elsawahli and Mohit, 2010; Hassan et al., 2011), Mexico, Brazil, Portuguese (Córtes et al., 2016), Spain (Vicente-Molina et al., 2013), India (Panth et al., 2015), Israel (Yavetz et al., 2009), Bangladesh (Ullah et al., 2013), United Arab Emirates (UAE) (AlMenhali et al., 2018), Yemen (Abdulrab, 2015), Poland (Demeskhant, 2013), Serbia (Major et al., 2017), Romania (Crumpei et al., 2014), Hungary (Zsóka et al., 2013), Ireland (Nicolaou and Conlon, 2013) aimed at determining the environmental attitudes, awareness and behaviour of university students.

Researchers claim that students' behaviour is affected and formed by their existing environment (Asunta, 2004; Lukman et al., 2013); some of which are namely: family, friends, neighbours, and cultural values. Different research revealed contradictive results for above-mentioned factors. Also, other variables such as educational background, the field of study, family income, parental education, parental occupations and where they live revealed a similar contradiction. Following this, some of this research specifically concentrated on demographic factors (Meyer, 2016; Sharma, 2014; Vicente-Molina et al., 2018), others focused on cultural factors (Córtes et al., 2016; Kaplowitz and Levine, 2005; Kilbourne and Polonsky, 2005; Major et al., 2017; Vicente-Molina et al., 2013). Researchers also wanted to reveal whether the major student study could be an influencing factor (Budak et al., 2005; Chen and Tsai, 2016; Demeskhant, 2013; Duman-Yuksel and Ozkazanc, 2015; Kiper, 2014; Nicolaou and Conlon, 2013; Pan et al., 2018). While the majority of the research was conducted on university students in general, there is substantial research on the teacher candidate students (Goldman et al., 2006; Ozden, 2008; Pe'er et al., 2007; Tuncer et al., 2009; Yavetz et al., 2009).

The purpose of this study is to explore undergraduate students' awareness and behavioural patterns towards the environmental problems at Bursa Uludag University in Turkey. The city of Bursa is founded in one of the most fertile plains of Turkey (Eisenlohr et al., 1995). It is believed that this research in Bursa with three million residents (TurkStat, 2017) and about 75 thousand students (Bursa Uludag University, 2018) will provide significant results for the field. It will allow researchers to compare the results of the current research and shed light on the issues raised in previous researchers.

\section{Materials and methods}

\section{The universe and the sampling}

This study was carried out at Bursa Uludag University, Turkey. Bursa Uludag University is the seventh largest university in Turkey (Higher Education Council, 2018). It accommodates 74822 students 42917 of whom undergraduate, in 14 faculties, 4 institutes, and 15 vocational schools. 10 of the 14 faculties are located on the central campus, Gorukle. The number of students here was 47138 in the 2017-2018 academic year (Bursa Uludag University, 2018). Other faculties and vocational high schools are distributed in various districts of the province. However, this research is limited to Gorukle campus and 9 faculties, taking the student distribution rates of the faculties into consideration and the transportation restrictions of the campuses in the districts.

For this research, a structured questionnaire was prepared by carefully scanning the existing literature and reviewing the previous work. At the beginning of the lecture, the students were asked to fill in this questionnaire under the supervision of the trained interviewers with the permission of the lecturer. The age of the students varies between 
18 and 24 in 4-year faculties, while the rate of the Medical School varies between 18-26, 18-21 in vocational schools, and 18-26 in Art School. The research was carried out from March to May 2018.

The sample size was determined by estimating a proportion formula used by Thompson (2012). To obtain an estimator $p$ having probability at least $1-\alpha$ of being no farther than $d$ from the population proportion, the sample size formula based on the normal approximation gives

$$
n=\frac{N p(1-p)}{(N-1)\left(\frac{d^{2}}{z^{2}}\right)+p(1-p)}
$$

Hence, the minimum sample size was found to be 680 (32 questionnaires were discarded because they were incomplete, resulting in a valid sample of 648 individuals).

\section{Data collection}

The survey questionnaire consisted of 32 questions in three parts: The first part contained items to measure the socio-demographic and economic characteristics of the students such as gender, family income; parental education and parental occupation (see Appendix). In the second part, students were asked to describe 'environment' and 'environmental pollution' with their own words in two open-ended questions. Openended questions allow participants to express their views without being affected by the researcher (Foddy, 1993). However, open-ended questions also have drawbacks in comparison to close-ended questions. They require extensive coding and often result in significantly larger nonresponse rate (including 'Don't know', 'Prefer not to answer' and blanks) (Dohrenwend, 1965). Further, four multiple choice and one 'yes' and 'no' questions were asked. The third part included 14 items to measure the students' environmental behaviour and attitude. They were asked to indicate what extent they participate in the statements in the questionnaire on a 5 point Likert type scale. $(1=$ Strongly Disagree; 2 = Disagree; 3 = No opinion, $4=$ Agree, $5=$ Strongly Agree) .

SPSS 23.00 package was used to analyse the data. The Independent Sample T-test and the One-way ANOVA were performed to reveal the relationships between the variables.

The Cronbach Alpha reliability coefficient of the survey was found to be $\alpha=0.731$. A Shapiro-Wilk test was used to test for normality assumption. The analysis showed that $[D(648) p<0.001]$ the data does not show normal distribution. Therefore, the skewness and kurtosis values are further used and skewness of $0.132(S E=0.096)$ and kurtosis of $0.329(S E=0.192)$ was found. As the Skewness and kurtosis values are between +1.5 and -1.5 , recommended by Tabachnick and Fidell (2013), the normality assumption is accepted.

\section{Results and discussion}

\section{General characteristics of participants}

Of the 648 respondents, $47.2 \%$ were female and $52.8 \%$ were male. Around $33.3 \%$ were from the Faculty of Economic and Administrative Sciences, $12.42 \%$ were from the Faculty of Education. Detailed respondent distribution of faculties is given in Table 1. 
Table 1. Respondent distribution of faculties

\begin{tabular}{c|c|c|c}
\hline & Frequency & Valid \% & Cumulative \% \\
\hline Education & 96 & 14.8 & 14.8 \\
Arts and Sciences & 66 & 10.2 & 25.0 \\
Science and Life Sciences & 66 & 10.2 & 35.2 \\
Economic and Administrative Sciences & 216 & 33.3 & 68.5 \\
Engineering and Architecture* & 66 & 10.2 & 78.7 \\
Medicine & 36 & 5.6 & 84.3 \\
Veterinary & 48 & 7.4 & 91.7 \\
Agriculture & 54 & 8.3 & 100.0 \\
\hline TOTAL & 648 & 100.0 & \\
\hline
\end{tabular}

*The results of the Faculty of Architecture and Engineering are combined

$30.6 \%$ of participants' family income fell between $\$ 588-640$. This means both parents work in the family but they earn minimum wage. Almost a quarter of students family income $(24.1 \%)$ is around legal salary, meaning only one of the parents contribute to the family budget at the minimum wage level. $22.2 \%$ of the students reported to have a family income less then minimum level meaning none of the parents actively work, they are either unemployed or retired. Half of the students' mothers had only compulsory basic education $(50.9 \%$ ) while $21.3 \%$ of their fathers had a university degree. As the income of the family and education of the household reflects, a large majority $(80 \%)$ of the participants' mothers are housewives. Table 2 shows that only $16.7 \%$ of the mothers found to be working and providing income for the family. $21.3 \%$ of fathers was retired and 3.7\% were unemployed, therefore, a quarter of participants' fathers were actively employed.

\section{Demographic findings}

\section{Gender}

In order to assess the gender effect on student environmental awareness and attitude, an independent samples $t$-test was conducted. The result indicated that there was no significant difference in gender effect between males and females, $t(646)=-0.528$, $p=0.598$ (Table 3).

Many studies examining the effects of gender on environmental attitudes and behaviour stated that there is no meaningful and consistent relationship between gender and environmental attitudes (Isildar and Yildirim, 2008; Kanbak, 2015; McDaniel and Alley, 2005; Robinson and Crowther, 2001; Sadik and Sadik, 2014; Stern et al., 1995; Zelezny et al., 2000). Artun et al. (2013) and Timur and Yilmaz (2011) show that gender is not influential at the levels of environmental literacy of teacher candidates. The participants' gender has not been prevalent in their environmental judgments either (Ozdemir et al., 2004; Sever and Yalcinkaya, 2012; Sungur, 2017). Genc and Genc (2013) and Gercek (2016) concluded that students' perception of environmental ethics did not differ significantly according to their gender. Stated examples underline the outcome of this research. 
Table 2. Summary of demographic variables

\begin{tabular}{|c|c|c|c|c|c|c|c|c|c|}
\hline & $\mathbf{n}$ & $\%$ & $\mathbf{M}$ & SD & & $\mathbf{n}$ & $\%$ & $\mathbf{M}$ & SD \\
\hline$\underline{\text { Gender }}$ & & & & & $\underline{\text { Family income } \$ *}$ & & & & \\
\hline Female & 306 & 47.2 & 0.48 & 0.48 & 0-294 & 156 & 24.1 & 2.06 & 0.43 \\
\hline Male & 342 & 52.8 & 0.48 & 0.48 & $295-587$ & 144 & 22.2 & 2.41 & 0.58 \\
\hline Total & 648 & 100 & 2.31 & 0.48 & $588-640$ & 198 & 30.6 & 2.37 & 0.42 \\
\hline & & & & & $641-900$ & 78 & 12 & 2.4 & 0.49 \\
\hline & & & & & $901+$ & 72 & 11.1 & 2.38 & 0.34 \\
\hline & & & & & Total & 648 & 100 & 2.31 & 0.48 \\
\hline Mother's education & & & & & $\underline{\text { Father's education }}$ & & & & \\
\hline Literate & 72 & 11.1 & 2.05 & 0.45 & Literate & 30 & 4.6 & 2.43 & 0.78 \\
\hline Primary education & 330 & 50.9 & 2.32 & 0.46 & Primary education & 264 & 40.7 & 2.29 & 0.46 \\
\hline Secondary education & 192 & 29.6 & 2.45 & 0.49 & Secondary education & 216 & 33.3 & 2.27 & 0.5 \\
\hline University education & 54 & 8.3 & 2.11 & 0.4 & University education & 138 & 21.3 & 2.39 & 0.4 \\
\hline Total & 648 & 100 & 2.31 & 0.48 & Total & 648 & 100 & 2.31 & 0.48 \\
\hline Mother's occupation & & & & & Father's occupation & & & & \\
\hline Housewife & 516 & 79.6 & 2.31 & 0.47 & Self employed & 156 & 24.1 & 2.42 & 0.44 \\
\hline White collar & 36 & 5.6 & 2.60 & 0.54 & White collar & 78 & 12 & 2.40 & 0.22 \\
\hline Blue collar & 54 & 8.3 & 2.22 & 0.45 & Farmer & 30 & 4.6 & 2.03 & 0.29 \\
\hline Self employed & 18 & 2.8 & 2.45 & 0.42 & Blue collar & 138 & 34.3 & 2.4 & 0.44 \\
\hline Other & 24 & 3.7 & 1.88 & 0.43 & Retired & 222 & 21.3 & 2.2 & 0.57 \\
\hline \multirow{2}{*}{ Total } & 648 & 100 & 2.31 & 0.48 & Unemployed & 24 & 3.7 & 2.09 & 0.48 \\
\hline & & & & & Total & 648 & 100 & 2.31 & 0.48 \\
\hline
\end{tabular}

*Converted to $\$$ on the exchange rate Central Bank of the Republic of Turkey on 14.11.2018. Min legal salary 2018 Gross (Monthly) 2.029,50 TL. Min legal salary 2018 Net (Monthly): 1.603,12 TL. Exchange rate Dollar buy: $1 \$=5.4625 \mathrm{TL}$, Dollar sell: $1 \$=5.4724 \mathrm{TL}$

Table 3. An independent sample t-test outcome for gender variable

\begin{tabular}{c|c|c|c|c|c|c}
\hline Gender & $\mathbf{N}$ & $\overline{\mathbf{X}}$ & $\mathbf{S d}$ & $\mathbf{D f}$ & $\mathbf{t}$ & $\mathbf{p}$ \\
\hline Female & 306 & 2.30 & 0.479 & 646 & \multirow{2}{*}{0.528} & \multirow{2}{*}{0.598} \\
Male & 342 & 2.32 & 0.482 & & & \\
\hline
\end{tabular}

\section{Family income}

Many research reviled middle and lower middle-class families display lower level attitudes toward the environment than more affluent families (Altin et al., 2002; Sama, 2003; Tekin and Gunes, 2018; Yilmaz and Erkal, 2016). de la Vega (2006) in his study on students and parents in Southwest Florida, showed parental income did not make any significant difference for awareness or knowledge. However, he observed a significant difference in their attitudes. Parent with an annual income of $>\$ 15,000$ scored considerably lower in attitude compared to parent with an income of $\$ 15,000-29,000$.

A one-way ANOVA was conducted to reveal whether family income affects students' environmental attitudes (Table 4). An analysis of variance showed that family income on the level of their environmental attitude was significant $[F(4,643)=15.09$, $p<0.001]$. In order to find out which income levels differ on the environmental 
attitude, post hoc comparisons using the Tamhane's T2 test was performed. Results indicate that only children of families with the lowest income group $(2.06 \pm 0.43)$ differ in terms of their environmental attitudes from children of families with all other income groups (please refer to Table 2 for means scores).

Table 4. Analysis of variance (ANOVA) between demographic variables and university students' environmental attitude

\begin{tabular}{c|c|c|c|c}
\hline & $\boldsymbol{d} \boldsymbol{f}$ & $\boldsymbol{M S}$ & $\boldsymbol{F}$ & $\boldsymbol{p}$ \\
\hline Family income & 4 & 3.21 & 15.09 & $0.000^{*}$ \\
Fathers education & 3 & 3.52 & 16.34 & $0.000^{*}$ \\
Mothers education & 3 & 0.59 & 2.57 & 0.053 \\
Mothers occupation & 4 & 2.06 & 9.40 & $0.000^{*}$ \\
Fathers occupation & 5 & 1.96 & 9.01 & $0.000^{*}$ \\
Field of study & 7 & 1.877 & 8.811 & $0.000^{*}$ \\
\hline
\end{tabular}

$* \mathrm{p}<0.001$

University students belong to the lowest income level $(\$<294 ; 2.06 \pm 0.43)$ differ from all other income levels in their awareness levels. Students from other income levels do not exhibit any statistically meaningful difference in their awareness. This result partially supports to the findings of Altin et al. (2002), Sama (2003), Tekin and Gunes (2018) and Yilmaz and Erkal (2016) that lowest level income groups displayed lower levels of environmental awareness means. On the other hand, students from families of all other income levels scoring very close means, suggest that parental income only significant at a point but not as a whole. This fact is in line with the findings of de la Vega (2006). It suggests that parental income is only of the utmost importance in the lowest income group and not meaningful for all other income groups

\section{Parental educational and occupational analysis}

Whether parents' educational levels and their occupation affect students' attitude and behaviour has been investigated thoroughly in the literature. Children learn by observing and imitating their parents, therefore, what goes on within the family may affect the formation of children's' environmental attitude and consequently their behaviour. Students raised by highly educated parents especially by educated mothers are expected to demonstrate a higher level of environmental awareness and attitude. The substantial number of research found a positive significant relation between parents' occupation and educational level and students' behaviour. Especially 'mothers' levels of education claimed to have a more positive effect on students' behaviour (Altin et al,. 2002; Bozoglu et al., 2016; Erol and Gezer, 2006; Goldman et al., 2006; Kanbak, 2015; Kayali, 2010; Kose et al., 2011; Ozden, 2008; Ozmen et al., 2005; Pe'er et al., 2007; Sam et al., 2010; Sama, 2003; Tekin and Gunes, 2018; Timur and Yilmaz, 2011; Yilmaz and Erkal, 2016; Vaizoglu et al., 2005; Zuzovsky, 2001).

A one-way ANOVA was conducted to reveal whether parental educational level affects students' environmental attitudes (Table 4). Statistically significant difference was found between mothers' educational level and students' environmental attitude $[F$ $(3,644)=16.34, p<0.001]$. Tukey post-hoc comparison reveals that children with 
literate mothers $(2.05 \pm 0.45)$, and mothers with primary $(2.32 \pm 0.46)$ and secondary $(2.45 \pm 0.40)$ education differ significantly between their environmental attitudes. Interestingly, no statistically significance found between the children of literate mothers and those having mothers with university education $(2.11 \pm 0.40)$.

Result confirms that as mothers' education levels increases, the environmental awareness of their children increases.

A one-way ANOVA was conducted to reveal whether mothers' occupation affects students' environmental attitudes. A statistically significant difference found between mothers' occupation and students' environmental attitude $[F(4,643)=9.40, p<0.001]$. Tukey post-hoc comparison reveals that children's of white collar $(2.60 \pm 0.54)$ mothers significantly differ from the ones with blue-collar $(2.25 \pm 0.45)$ and housewife mothers $(2.31 \pm 0.47)$. No statistical significance observed between housewife and blue-collar mothers children environmental attitude. Therefore, it can be said that mothers's occupation has a positive impact on their children's environmental attitudes.

Another one-way ANOVA analysis was performed to analyse whether fathers' education affects their children's environmental attitudes. No statistically significant difference observed between fathers education and students' environmental attitude $[F$ $(3,644)=2.57, p=0.053$.

Despite the fact that the education level of fathers does not significantly affect the environmental awareness of children, their professional status found to be highly influential $[F(5,642)=9.01, p<0.001]$. This effect is much more significant than the mothers' professional status. Post hoc comparisons using the Tamhane's T2 test indicated the children of working fathers (white-collar $(2.40 \pm 0.44)$, self-employed $(2.42 \pm 0.44)$ and blue-collar $(2.40 \pm 0.44)$ have a higher environmental awareness. There was no statistically significant difference between the non-working (retired $(2.20 \pm 0.57)$; unemployed $(2.09 \pm 0.48))$ and farmer $(2.03 \pm 0.29)$ fathers' children. Participants who have farmers father have shown the least environmental awareness. It is thought that the fact that farmers work under very difficult conditions and have very little income has an important effect on this finding.

\section{Field of study}

The study field and environmental attitudes that students exhibited was one of the variables included in almost every research conducted in the field. The aim is to see whether the environmental attitudes and behaviour of the students have an impact on the selection of the subject they attend at the university and to examine whether the subject they choose and faculty they attend have impacted on their environmental attitudes and behaviour.

Research on the universities reveals many contradictions. For example, a study by Ozmen et al. (2005) found that the Medical School and Health Science Vocational School Students 'Environmental Attitude Scale' results are higher 'Health Services Vocational School.' Similarly, Kolomuc et al. (2013), Oguz et al. (2011) and Talay et al. (2004) found that Heath Sciences students were more knowledgeable in subjects such as air pollution, organic farming and environmental problems. In contrast, Tekin and Gunes (2018) found the students of the Faculty of Dentistry scored the lowest level of environmental behaviour. Kaplowitz and Levine (2005) stated the five highest scoring colleges are the Colleges of Osteopathic Medicine, Human Medicine, Agriculture and Natural Resources, Veterinary Medicine and Natural Science. Tekin and Gunes (2018), Kose et al. (2011), Ek et al. (2009) and Ozmen et al. (2005) found 
that Economic and Administrative Sciences students displayed more positive environmental attitudes than Engineering students. Yazici and Babalik (2016) found students of social sciences consider recycling important more than others. In contrast, Benton and Funkhouser (1994) and Benton (1994) consistently found business students lag behind their peers.

Goldman et al. (2006) reveal that students who study in environmentally affiliated subject achieved a higher overall mean score for environmental behaviour than nonenvironmentally affiliated fields. In the same line, Tikka et al. (2000) found biology and forestry student displayed the highest levels of environmentally related activities. Vicente-Molina $(2013,2018)$ in the US and Spain found that science and engineering students are more likely to behave pro-environmentally than social science students.

One-way ANOVA using post hoc Tamhane's T2 test was undertaken to see if the field of study affects students' environmental attitudes. Statistically significant difference observed between the students' field of study and their environmental attitude $[F(7,640)=8.81, p<0.001]$. Medical School students $(2.48 \pm 0.34)$ displayed the highest level of environmental awareness followed by Business School (2.41 \pm 0.49$)$ and Veterinary School $(2.40 \pm 0.53)$. In contrast to Kaplowitz and Levine (2005), agriculture students achieved the lowest mean scores $(2.05 \pm 0.36,95 \%)$ along with the Science and Life Sciences $(2.07 \pm 0.51)$ students.

This research outcome confirms the findings of Oguz et al. (2011), Ozmen et al. (2005) and Talay et al. (2004). Kolomuc et al. (2013) underline Medical students have the highest environmental awareness $(M=2.48)$. Benton (1994) and Benton and Funkhouser (1994) consistently confirmed that business students lagged behind their peers. In contrast, this research revealed the opposite. While this research did not analyse particular branches, the School of Education where prospect teachers are educated achieved a medium level of awareness (2.39 \pm 0.45$)$. Students' scoring average to lower level in the science faculties can be interpreted as not a failure of the curriculum but of the poor performance of the university itself. Students of agriculture may be expected to score the much higher because they are supposed to be more knowledgeable about the causes and consequences of environmental problems. This is particularly important for Turkish content because while Turkey has been making efforts to expand its industry, agriculture still maintains its importance.

Faculty distribution of the environmental problems perceived by students may reveal a more fruitful picture (Table 5).

Table 5. Faculty distribution of the most important problems perceived by students

\begin{tabular}{c|c|c|c|c|c|c|c|c}
\hline \multirow{2}{*}{ Field of study } & \multicolumn{9}{c}{ \% } \\
\cline { 2 - 8 } & Air & Water & Soil & Noise & CC/GW & UU & Other & Total \\
\hline Education & 18.8 & 18.8 & 0.0 & 18.8 & $\mathbf{2 5 . 0}$ & 6.3 & 12.5 & 100.0 \\
Arts and Sciences & 18.2 & $\mathbf{3 6 . 4}$ & 0.0 & 0.0 & 18.2 & 27.3 & 0.0 & 100.0 \\
Science and Life Sciences & 9.1 & 9.1 & 9.1 & $\mathbf{2 7 . 3}$ & 9.1 & 36.4 & 0.0 & 100.0 \\
Business School & 22.2 & 13.9 & 8.3 & 2.8 & 13.9 & 33.3 & 5.6 & 100.0 \\
Engineering and Architecture & 9.1 & 18.2 & 9.1 & 18.2 & 18.2 & 27.3 & 0.0 & 100.0 \\
Medical School & $\mathbf{5 0 . 0}$ & 0.0 & 0.0 & 0.0 & 16.7 & 33.3 & 0.0 & 100.0 \\
Veterinary & 0.0 & 25.0 & 0.0 & 12.5 & 12.5 & $\mathbf{3 7 . 5}$ & 12.5 & 100.0 \\
Agriculture & 22.2 & 0.0 & $\mathbf{3 3 . 3}$ & 0.0 & 11.1 & 33.3 & 0.0 & 100.0 \\
\hline TOTAL & 18.5 & 15.7 & 7.4 & 9.3 & 15.7 & 28.7 & 4.6 & 100.0 \\
\hline
\end{tabular}

CC: climate change, GW: global warming, UU: unplanned urbanisation 
The medical student stated air pollution as a serious environmental problem by $50 \%$. This may be that respiratory illnesses once were frequent in winter times are spreading over all seasons and increasing its intensity. Therefore, air pollution-related illnesses are becoming more visible. On the other hand, arts and science students thought water pollution is an environmental threat (36.4\%). As expected, third of agriculture students were concerned with soil pollution. On the other hand, climate change, global warming and urbanisation were a common concern across faculties. Veterinary schools concern with urbanisation is striking (37.5\%). Perhaps unlike agricultural student whom urbanisation obliterates their work field, urbanisation creates additional problems to a veterinary specialist such as strayed and starved animals.

\section{Fundamentals of environmental awareness}

The second part of the questionnaire aimed to analyse students' environmental knowledge. They were given two open-ended questions and asked to describe 'environment' and 'pollution' with their own words in 'one sentence'. Two-thirds of students left these two questions blank and other students only written unrelated single words. Stated words did not provide sufficient data to make a meaningful content analysis which is often the problem with open-ended questions. Students also did not give reasoning when they have chosen 'other' option on the 'multiple choice' questions.

When students were asked to state 'the most important environmental problem of Turkey', almost a third of them declared this as 'unplanned urbanisations'. Turkey is a developing country. 23.4\% of citizens are between 15-29 years old (19 183 261; TurkStat, 2018a). Unemployment rate is $10.9 \%$ and non-agricultural unemployment rate is $13.0 \%$ (TurkStat, 2018b). Domestic immigration is over 20\% in some cities (Tekirdag 20.8\%, Yalova 20.2\%). This figure is $14.7 \%$ in another industrial city Kocaeli, $7.2 \%$ in Bursa. High young population and unemployment rate lead to a high labour migration, which lays the ground for unplanned urbanisation. In fact, this cause new environmental problems such as traffic, air, water and noise pollution, loss of fertile land and deterioration of the natural environment and also accelerate existing problems. Therefore, for students in Bursa, the fourth most populous and seventh largest industrial city of Turkey, this finding is not surprising. Air pollution ranked second and water pollution ranked third equality with climate change and global warming. Interestingly soil pollution ranked the least important problem.

There found no significant differences between women and men in the answers given according to gender. In males, unplanned urbanisation $(35.1 \%)$ and air pollution $(19.3 \%)$ were higher than females, whereas, in females, water pollution and global warming (19.6\%) were higher than males (Table 6).

Ullah et al. (2013) in their study in Bangladesh cited unplanned urbanisation (32\%) as the major problem followed by air pollution (17\%) and soil pollution and loss of farmland (13.5\%). Sadik and Sadik (2014) research on the teacher candidate students of social sciences in Adana revealed similar result: urbanisation was found the most serious problem (28.5\%) and population growth (10.8\%) ranked second. Kulozu (2016) in Ataturk University also identified unplanned urbanisation $(27.3 \%)$ highest followed by air pollution $(20.9 \%)$ and environmental pollution $(18.5 \%)$. In the same line, male students in Hatay ranked urbanisation as the most serious problem (Bozdogan et al., 2016). Gulgun et al. (2008) research similarly ranked the very same problem second (18.5\%) after air pollution (24.22\%). 
Table 6. What is the most important environmental problem in Turkey?

\begin{tabular}{c|c|c|c|c|c|c}
\hline & \multicolumn{2}{|c|}{$\begin{array}{c}\text { Female } \\
\text { F \% }\end{array}$} & \multicolumn{2}{c|}{$\begin{array}{c}\text { Male } \\
\text { F \% }\end{array}$} & \multicolumn{2}{c}{$\begin{array}{c}\text { TOTAL } \\
\text { F \% }\end{array}$} \\
\hline Unplanned urbanisation & 66 & 21.6 & 120 & 35.1 & 186 & 28.7 \\
Air pollution & 54 & 17.6 & 66 & 19.3 & 120 & 18.5 \\
Water pollution & 60 & 19.6 & 42 & 12.3 & 102 & 15.7 \\
Climate change/global warming & 60 & 19.6 & 42 & 12.3 & 102 & 15.7 \\
Noise pollution & 30 & 9.8 & 30 & 8.8 & 60 & 9.3 \\
Soil pollution & 18 & 5.9 & 30 & 8.8 & 48 & 7.4 \\
Other & 18 & 5.9 & 12 & 3.5 & 30 & 4.6 \\
\hline TOTAL & 306 & 100 & 345 & 100 & 648 & 100 \\
\hline
\end{tabular}

Other research highlighted Ozdemir et al. (2004) stated that the problems of the Faculty of Medicine students in the first three ranks were air pollution with $37.5 \%$, waste disposal with $36.2 \%$ and deforestation with $30.6 \%$. The most important problems stated by the students of the Faculty of Health Education of Ankara University were air pollution with $49.5 \%$, environmental pollution with $26.6 \%$ and wastes with $25.7 \%$ (Celen et al., 2002). As for students of Landscape Architecture, Environmental Engineering and City and Regional Planning in Ankara, the most important environmental problem in Turkey is air pollution (17.1\%). It follows water pollution (14.9\%), urbanisation (14.3\%) and depletion of natural resources (14.3\%) (Oguz et al., 2011). Erdal et al. (2013) reveal similar findings: students consider air pollution (73.91\%) Turkey's most important environmental problem, followed by water $(60.87 \%)$, soil (33.99\%) and noise pollution (54.15\%). Kanbak (2015) reveals air pollution as first, water second and solid waste third-ranked problem for Physical Sciences at Kocaeli University. For Health and Social Sciences, air pollution comes first, forest destruction lands come second and solid waste problem comes third. According to students at Suleyman Demirel University, the most important environmental problems in Turkey are air pollution, forest loss and solid waste treatment (Yazici and Babalik, 2016). Bozdogan et al. (2016) cited air pollution is the most worried problems in females. Ozen and Ozen (2017) state the ranking of the Faculty of Veterinary Faculty of Firat University as air pollution, waste and water pollution.

Artun et al. (2013) indicated that 54\% of social studies teacher candidates chose global warming, $33 \%$ air pollution, $10 \%$ greenhouse gas, $10 \%$ distorted urbanisation, and 4\% ozone layer perforation. Yadav and Pathak (2013) research of female university students in Jharkhand India, reviled that $33 \%$ of respondents consider global warming as the main problem, $41.67 \%$ consider pollution followed by $33.33 \%$ air pollution, $33.33 \%$ ozone depletion, $25 \%$ water pollution, and $25 \%$ soil pollution. Ermolaeva (2010) in Fort Collins, Colorado illustrates that students are most worried about the destruction of wilderness and forests $(9.4 \%)$, air pollution $(9.3 \%)$, people's consumption habits $(8.9 \%)$, water pollution $(8.8 \%)$, growing waste/not enough recycling $(8.7 \%)$ and urban problems $(8.2 \%)$. Amongst the various environmental problems of China, students ranked water pollution as the most urgent (Wong, 2003). They ranked deforestation and soil erosion problems as the second and urban air pollution was as the third most urgent environmental problem. In the study conducted on medical students in Finland, more than half of the participants stated that the most important environmental risk was water pollution (Kasma-Ronkainen and Virokannas, 1996). 
The different answers given by the above studies show that the geographic and socioeconomic situation of the country and or the region affected the students' responses and the issues they prioritised changed. For example, surveys, where unplanned urbanisation is the highest, are usually developing countries like India and Turkey. Students who indicate priority problems as air and water pollution are seen to live in regions or countries they are overpopulated or naturally depleted of such resources.

Students were asked whether their university sensitive to environmental problems. An overwhelming number of students have disagreed (Table 7).

Table 7. Are universities susceptible to environmental problems?

\begin{tabular}{c|c|c|c}
\hline & Frequency & \% & Cumulative \% \\
\hline Yes & 162 & 25.0 & 25.0 \\
No & 486 & 75.0 & 100.0 \\
\hline TOTAL & 648 & 100.0 & \\
\hline
\end{tabular}

This finding is in line with Erdal et al. (2013) who revealed very similar result in Gazi Osman Pasa University in Tokat where $75.49 \%$ of students declared no and $24.1 \%$ declared yes. Oguz et al. (2011) also examined Landscape Architecture (Ankara University, Bilkent University), Environmental Engineering (Middle East Technical University) and City and Regional Planning (Middle East Technical University, Gazi University) in Ankara. Their score was 69\% 'no' and 31\% 'yes' to the same question. Similar results were revealed in Yazici and Babalik (2016) research at Suleyman Demirel University.

Students have given a unanimous reply to this statement. Such high numbers indicate that universities fail to achieve their part in protecting the environment. Since universities should be the forerunners of environmental protection, the reason why students have such low perceptions of their universities environmental sensitivity should be urgently and thoroughly analysed.

When students were asked the reason why there is no sensitivity to environmental problems in society (Table 8), the most striking answer was the lack of deterrent sanctions against environmental offenders (40.7\%). In the second statement, respondents admitted that although they were aware of environmental problems, they were reluctant to reflect this behaviour to their lives $(26.9 \%)$ and the consequences of environmental problems were not obvious to people (18.2\%). Only $4.6 \%$ claimed that institutions and organisations that are in charge of protecting the environment are not effective and $2.8 \%$ highlighted the need for training and education. On the other hand, Oguz et al. (2011) indicated highest ranked outcome with $32.9 \%$ that people are aware of the problems but do not act to protect it while Erdal et al. (2013) research achieved $21.99 \%$ to the very same statement. Being indifferent to the consequences of environmental problems scored $20.7 \%$ in Erdal et al. (2013) and 12.9\% in Oguz et al.'s (2011) research. Oppositely, inadequate education and not to witness implementation are regarded main reasons for lacking environmental sensitivity (Oguz et al., 2011, 31.4\%; Erdal et al., 2013, 24.3\%).

Another striking result of the survey was that non-governmental organisations (NGOs) (47.2\%) stood out in the evaluation of the organisation that made the most important contribution in the fight against environmental problems. Despite this finding, Korkmaz (2018) points out that NGO's activities in the environment in particular 
climate change are inadequate despite raising activities of civil society organisations. Universities $(2.8 \%)$ were considered the least contributing organisations (Table 9). The ministries (19.4\%) and public service announcements (18.5\%) ranked lower than NOGs. This research is in the same line with Erdal et al.'s (2013) research. There, student ranked NGOs work first with $38.74 \%$ but universities scored $16.21 \%$ unlike $2.8 \%$ that Bursa Uludag University scored. Related ministries scored $20.95 \%$ and charitable foundations achieved $24.11 \%$.

Table 8. What's the reason for not having sensitivity towards environmental problems?

\begin{tabular}{c|c|c|c}
\hline & Frequency & $\%$ & Cumulative \% \\
\hline The consequences of environmental problems are not known. & 120 & 18.5 & 18.5 \\
Deterrent punishment/sanctions not issued. & 264 & 40.7 & 59.3 \\
People are aware of environmental problems but they do not act to protect it. & 174 & 26.9 & 86.1 \\
Not enough education and implementation. & 18 & 2.8 & 88.9 \\
Shortage of relevant institutions. & 30 & 4.6 & 93.5 \\
Other & 42 & 6.5 & 100.0 \\
\hline TOTAL & 648 & 100.0 & \\
\hline
\end{tabular}

Table 9. Which organisation makes the most important contribution to prevent environmental problems?

\begin{tabular}{c|c|c|c}
\hline & F & \% & Cumulative \% \\
\hline Activities of non-governmental organisations & 306 & 47.2 & 47.2 \\
Public service announcements & 120 & 18.5 & 65.7 \\
Research and educational activities of universities & 18 & 2.8 & 68.5 \\
Works of the Ministry of Environment and Urbanism & 126 & 19.4 & 88.0 \\
Works of the municipalities & 78 & 12.0 & 100.0 \\
\hline TOTAL & 648 & 100.0 & \\
\hline
\end{tabular}

The students of the Faculty of Health Education stated that they rely on voluntary organisations at the highest rate $(92.5 \%)$ in solving environmental problems (Celen et al., 2002). 54.9\% of the students in the Faculty of Education at the Hacettepe University stated that the written and visual media were the most important agenda determinants and the least contributing group was the politicians (Yilmaz et al., 2002).

When students were asked the role of society in protecting the environment they stressed that people should take an active part in protecting the environment $(36.1 \%)$ (Table 10). As earlier question already pointed out, students believe that people are aware of the problems but they did not reflect this awareness into their behaviour. Despite students' statement of the most important environmental problem as urbanisation in the earlier question, preventing unplanned urbanisation was given the least importance $(3.7 \%)$. This finding must be investigated further. It had already been revealed that the work of related ministries and municipalities were considered unsatisfactory. Preparing city plans and deciding the way in which the city will expand is their work but citizens also play a pivotal role. It will not be realistic to expect from ministries or municipalities to prevent urbanisation problems or at least alleviate them. Society must be proactive preventing urbanisation problems. 
$34 \%$ of the students of Hacettepe University responded cared not to pollute the environment. This rate was $27.8 \%$ for Bursa Uludag University students. Moreover, $20 \%$ of the students in Hacettepe stated that people should use 'recycled materials' (Yilmaz et al., 2002). The same statement is marked by $17.6 \%$ in Uludag University.

Table 10. What is the role of society in protecting the environment?

\begin{tabular}{c|c|c|c}
\hline & F & \% & Cumulative \% \\
\hline To take care not to pollute the environment & 180 & 27.8 & 27.8 \\
To prevent unplanned urbanisation & 24 & 3.7 & 31.5 \\
To use environmentally friendly products & 114 & 17.6 & 49.1 \\
To actively take part in preserving the environment & 234 & 36.1 & 85.2 \\
Other & 96 & 14.8 & 100.0 \\
\hline TOTAL & 648 & 100.0 & \\
\hline
\end{tabular}

Bursa Uludag University students strongly emphasized (47.2\%), wanting to involve in the decision-making process. They also want to be able to monitor and evaluate the outcome of those decisions (Table 11). They stressed that environmental education should be compulsory throughout the university education. Only a handful of departments include environment related lectures in the curriculum. In fact, the majority of departments of social sciences, medicine and economics do not cover environmental issues in any way.

Table 11. What is the role of universities in protecting the environment?

\begin{tabular}{c|c|c|c}
\hline & F & \% & Cumulative \% \\
\hline Environmental education should be compulsory & 90 & 13.9 & 13.9 \\
Students should take part in the decision making and application process & 306 & 47.2 & 61.1 \\
More Research and Development activities should be organized & 90 & 13.9 & 75.0 \\
Should work in cooperation with the industry & 72 & 11.1 & 86.1 \\
Experimental waste should not be randomly disposed & 78 & 12.0 & 98.1 \\
Other & 12 & 1.9 & 100.0 \\
\hline TOTAL & 648 & 100.0 & \\
\hline
\end{tabular}

Various research highlights that they are in favour of mandatory environmental education (Ek et al., 2009, 84.1\%; Oguz et al., 2010, 93.4\%). Some stated that compulsory courses should be included in the curriculum at all educational stages (Ek et al., 2009, 33\%; Oguz et al., 2011, 74.4\%). Various researchers have specifically emphasized that a course on the environment at the university must be compulsory (Erdal et al., 2013, 65\%; Grodzinska-Jurczak and Trabula, 2001; Ozdemir et al., 2004, 61.7\%; Ozmen et al., 2005, 44.9\%).

The equal number of students also stressed that more research and development activities should be organized by the university. The substantial number of science students have witnessed the random disposal of experimental waste and raised their concern. Last but not the least, students expressed the need for more research and development but ranked working with the industry least important. 


\section{University students' attitudes and behavioural patterns towards environmental problems}

In the third part of the questionnaire, statements aimed to understand the students' awareness levels about environmental issues and to determine their attitudes at this awareness level. It is hoped that the answers to these questions will show the extent to which university students reflect their environmental attitudes to their behaviour. The questions and answers given in this section are given in Table 12.

Table 12. Questionnaire statements and responses $(n=648)$

\begin{tabular}{|c|c|c|c|c|c|c|c|}
\hline & 1 & 2 & 3 & 4 & 5 & M & SD \\
\hline $\begin{array}{l}\text { I have taken enough education on the environment at } \\
\text { school before the University. }\end{array}$ & $30.6 \%$ & $26.9 \%$ & $14.8 \%$ & $23.1 \%$ & $4.6 \%$ & 3.56 & 1.27 \\
\hline $\begin{array}{l}\text { I donate money or become a member of environment- } \\
\text { related organisations. }\end{array}$ & $13.9 \%$ & $27.8 \%$ & $24.1 \%$ & $30.6 \%$ & $3.7 \%$ & 3.18 & 1.12 \\
\hline When purchase. I prefer products & $17.6 \%$ & $12.0 \%$ & $33.3 \%$ & $26.9 \%$ & $10.2 \%$ & 3.00 & 1.23 \\
\hline $\begin{array}{l}\text { I prefer to read in a digital environme } \\
\text { to avoid paper was }\end{array}$ & $11.1 \%$ & $29.6 \%$ & $14.8 \%$ & $31.5 \%$ & $13.0 \%$ & 2.94 & 1.25 \\
\hline I take an active part in & $7.4 \%$ & $17.6 \%$ & $36.1 \%$ & $32.4 \%$ & $6.5 \%$ & 2.87 & 1.02 \\
\hline $\begin{array}{l}\text { I take care not to use consu } \\
\text { ozon }\end{array}$ & $3.7 \%$ & $18.5 \%$ & $30.6 \%$ & $32.4 \%$ & $14.8 \%$ & 2.64 & 1.06 \\
\hline $\begin{array}{l}\text { When I see someone po } \\
\text { remain unrespo }\end{array}$ & $5.6 \%$ & $10.2 \%$ & $34.3 \%$ & $31.5 \%$ & $18.5 \%$ & 2.53 & 1.08 \\
\hline $\begin{array}{l}\text { I dispose of materials sucl } \\
\text { etc. separately and }\end{array}$ & $2.8 \%$ & $7.4 \%$ & $18.5 \%$ & $39.8 \%$ & $31.5 \%$ & 2.10 & 1.02 \\
\hline When I nee & $0.9 \%$ & $9.3 \%$ & $11.1 \%$ & $42.6 \%$ & $36.1 \%$ & 1.96 & 0.96 \\
\hline I prefer to use public transport when I'm travelling. & $3.7 \%$ & $6.5 \%$ & $10.2 \%$ & $31.5 \%$ & $48.1 \%$ & 1.86 & 1.08 \\
\hline $\begin{array}{l}\text { I try to use resources suc } \\
\text { efficien }\end{array}$ & $0.9 \%$ & $3.7 \%$ & $7.4 \%$ & $41.7 \%$ & $46.3 \%$ & 1.71 & 0.83 \\
\hline I make sure that my rub & $0.9 \%$ & $1.9 \%$ & $6.5 \%$ & $13.9 \%$ & $76.9 \%$ & 1.36 & 0.76 \\
\hline $\begin{array}{l}\text { Our sensitivity to the environment is also our responsibility } \\
\text { to society. }\end{array}$ & $0.0 \%$ & $0.9 \%$ & $5.6 \%$ & $17.6 \%$ & $75.9 \%$ & 1.31 & 0.62 \\
\hline $\begin{array}{l}\text { I'm aware that environmental pollution is a problem for } \\
\text { future generations. }\end{array}$ & $1.9 \%$ & $0.0 \%$ & $3.7 \%$ & $14.8 \%$ & $79.6 \%$ & 1.30 & 0.71 \\
\hline
\end{tabular}

1: strongly disagree, 2: disagree, 3 : no opinion, 4: agree, 5: strongly agree

\section{Attitudes towards environmental problems}

Researchers in the field agree that students have not been able to convey the level of consciousness to their behaviour. According to Ullah et al. (2013) in Bangladesh, only $12 \%$ of students took part in environmental activism and only 35\% of them are interested in joining any environmental organisation. Hassan et al. (2011) found that UKM students in Malaysia had a high level of knowledge, awareness and attitudes about the environment, but low prevalence of participation in environmental activities. This view is supported by Wahida et al. (2004) (cited in Hassan et al., 2011). They say that awareness towards environmental issues and awareness about the need to protect the environment has increased among society, but the level of individual participation in protection activities still remains low. Azizan's (2008) (cited in Hassan et al., 2011) findings also support Wahida et al. (2004) (cited in Hassan et al., 2011). He underlines 
that the students have a good awareness of environmental problems but have not yet taken this awareness into action.

In support of the above argument, the result of this research indicates that the students who are actively involved in protecting the environment remain at $38.9 \%$. Comparison to other research, Oguz et al. (2011) revealed similar results: $39 \%$ of the students actively involved in activities related to environmental issues. Gulgun et al. (2008) showed a more optimistic figure: more than half of the students (56.4\%) actively involved in these activities. Kiper (2014) found $72.1 \%$ of the students were 'sometimes' active. The most worrying response came from Ozmen et al. (2005); 84.9\% of the students did not participate in any environmental activities.

It is not surprising that the ratio of students who actively participate in the events related to environmental issues, and the ratio of those who are members or donate to the environment-related organisations are close $(34.3 \%)$. The findings of the previous research similarly reveal low participation rates. Wong (2003) found that $6 \%$ of the students, Budak et al. (2005), 12.9\% and Timur and Yilmaz (2011), 17.4\% of student were members of the mentioned organisations. Wong (2003) in China further showed only $1.7 \%$ of the students was active members of such organisations.

It may be assumed that the income level of the students participating in the study is at the lower and middle class; hence affects their ability to pay their membership fees or to donate to such institutions. However, the general finding in the literature is that students do not participate in studies and activities on environmental issues regardless of income level. For example, Cabuk and Karacaoglu (2003) asked students whether they participate in volunteer organisations working on the environment and the reply was 52.2\% 'sometimes', and 38.7\% 'never.' Isildar and Yildirim (2008) showed a more negative result: $21.7 \%$ of the students said 'sometimes', $65.2 \%$ said 'never'. In the Kanbak (2015) survey, $62.6 \%$ of the respondents said that they did not participate in the activities of any environmental organisation.

What is important here is that although more than half of the students $(57.5 \%)$ state that they have not received any education about the environment before the university, they are still reluctant to participate in such events and improve their knowledge of the environment. One of the outcomes of this low educational level is the inability to define the concepts of environment and pollution in their own words in the previous section of the questionnaire. The previous research in the field gives contradictory results to this statement as well. For example, Ozdemir et al. (2004) reported $94.4 \%$ of the students received environmental education at any time during their education. $75.9 \%$ of the participants in Ozmen et al. (2005), 44\% of the participants in Erdal et al. (2013), and $47.2 \%$ of the participants in Kiper (2014)'s research reported receiving environmental education before the university. Paksoy and Paksoy (2015) stated that 35\% of the students received environmental education at primary and $23 \%$ at the secondary education.

Despite the inadequate education, knowledge base and lack of willingness to participate in environmental problems, an overwhelming percentage of the students (94.4\%) agree that environmental pollution will pose a problem for future generations. They also realise that sensitivity towards environmental problems means also a responsibility to society $(93.5 \%)$. Students are once again in contradiction with themselves, while they are reluctant to join environmental organisations and participate in their activities, they are almost unanimous in agreeing that it is a social duty to protect the environment. 
The other contradiction posed by the students is that, although they think it is a social duty to protect the environment, when it comes to 'warning' someone polluting the environment they remain 'indifferent.' Only $10.2 \%$ 'agreed' that they warn people and $5.6 \%$ strongly agreed, $34.3 \%$ was 'unresponsive' and 31.5\% 'disagreed.' In fact, this ratio coincides with the rates of participation in environmental activities and membership to related organisations.

These results bring the following question to mind. If a student really believes that environmental protection is a social duty and pollution is a threat to the future, why do they not play an active role in protecting the environment? The fact that students expect others to display 'behaviour' that they do not do 'themselves' can be interpreted in two ways: One of them is social desirability bias. Social desirability is the tendency to respond to question in a manner that will be viewed favourably by others. They do this to exhibit a positive image of themselves to avoid receiving an unfavourable opinion. This could lead to either over-reporting 'right' behaviour' or under-reporting 'bad' or 'undesirable' behaviour (Fisher, 1993). Or they really feel the need to protect the environment and warn those who do not fulfil their environmental responsibilities. However, they are unable to put their intentions into action for various reasons such as being condemned by people, judged as disrespectful and not knowing the legal sanctions.

Although other researchers in the field have reported higher figures, they have shown that students, in general, are reluctant to warn the polluters. Ullah et al. (2013) in Bangladesh reported $56.5 \%$ of those to warn them. This ratio is $47 \%$ in Paksoy and Paksoy's (2015) and 44.2\% in Kiper's (2014) work.

\section{Purchasing and disposing behaviour}

In the introduction section of the article, it was stated that having knowledge about the environment affects the attitudes of the individual in a positive way (Sivek and Hungerford, 1990) and that the positive attitude leads to positive behaviour (Wang et al., 2014).

The statements that measured the students' attitudes did not display a very revealing picture. It was observed that the students were not knowledgeable about the environment and did not have a positive attitude towards the environmental problems.

The survey included eight statements aimed at determining students' environmental behaviour. The extent to which students' responses reflect their attitudes to their behaviour is examined below.

When the university students behavioural patterns were examined, the lowest mean $(M=1.30)$ was obtained from the statement indicating that 'they make sure their rubbish goes into the garbage bin'. $90.8 \%$ of the participants state that they pay attention. It is expected that young people with university education will reflect this sensitivity. To see the actual behavioural patterns, it is necessary to evaluate other statements.

When examined in into more depth, it is observed that the ratio of the students who sorted their garbage as plastic, glass, paper, battery and disposed of separately, decreased to $71.3 \%$. It is also noteworthy that the ratio of those who say they have 'no opinion' is close to $20 \%$. Kiper's (2014) research has also yielded more concerning results; while $24.4 \%$ of those who say they always sort household waste out, $19.8 \%$ said that they never do it. 
Recyclable packaging has been on the market for more than two decades. The benefit of recycling to the environment and the country's economy is often emphasized in the written and visual media, and publications that attempt to raise public awareness about the use of recyclable products are widely available. Perhaps, due to this emphasis, young people may have had the illusion that all products are sold in recycled packages or that each product is recyclable. Likewise, when purchasing a product, the ratio of those agreed that they make sure that the product is in recycled packaging, dropped to $37.1 \%$. The ratio of those who said they absolutely agreed with the statement, further dropped to $20.2 \%$. The ratio of those who strongly disagreed being $17.6 \%$, is concerning. Present results despite not being promising, are not far from other studies undertaken. Kiper (2014) studied the environmental attitudes of Landscape Architecture students and he observed that $40.7 \%$ of those claimed 'always' paid attention. Erdal et al.'s (2013) study showed a similar outcome with the current research results. In his study, those who absolutely agreed were $26.48 \%$ partially agreed were $28.46 \%$.

On the other hand, the rate of those who participated in the statement that they chose products that would not harm the ozone layer increased to $47.2 \%$. The findings of the present research are consistent with previous research. Paksoy and Paksoy (2015) research states $43 \%$ of the participants, Gulgun et al.'s (2008) research states $39.23 \%$ of them do not use the products that damaged the ozone layer. However, it is striking that in both statements, a third of the students said "they had no idea".

As in the previous statement, the students indicating that they use natural resources such as electricity, water and natural gas sparingly reached to $90 \%$. Especially in developing countries, utility bills amount higher than in developed countries and constitute a significant portion of the household budget. Therefore, the careful use of these resources may reflect the environmental consciousness of the students and or may have acquired as a result of a necessity imposed by their parents because participating students are usually from families belonging to the lower and middle-income groups

Above findings may be interpreted as the fact that the participant students are generally in low and middle-income families, therefore they rather pay more attention to the price of the product rather than its eco-friendly properties.

As a result of technological developments in recent years, people especially young people use digital environments increasingly. Consequently, various studies are carried out to monitor their digital literacy development. Many businesses have adopted paperless office principles for over a decade. Bookstores have extended their e-book range, and universities have started to broadcast lectures online and moved lecture material to the virtual environment. Students were asked a special question about whether they read in digital media to save paper. Research findings showed that students do not prefer to read in digital media, contrary to common assumption. Only half of the students $(44.5 \%)$ read on screen. $40.7 \%$ still prints the lecture notes and they do seem to concern with paper saving.

Despite not reading from the screen, students were sensitive about paper use. $48.1 \%$ was 'strongly agreed' and $35.1 \%$ 'agreed'. $78.7 \%$ of the respondent stated that they used both sides of papers. Nevertheless, the rate of those who said that they would definitely use double-sided paper is behind the findings of other studies. Cabuk and Karacaoglu (2003) came up with the figures of 'always' $63.8 \%$, and 'sometimes' $30.1 \%$. Whereas Erdal et al. (2013) found those who 'absolutely agree' with were $51.38 \%$, and those who 'agree with' were $33.20 \%$ 
Car ownership is regarded as a symbol of economic welfare and social status in many countries. Nonetheless, the public transport usage rate depends on the availability of alternatives. Bicycle usage is a new phenomenon in Turkey. Urban metro is also available only in a few major cities and suburban train network is almost negligent. In addition, universities can develop a variety of approaches depending on whether they are in rural or urban areas. In small cities, students can have easier access by foot or by bicycle. This present research reveals $79.6 \%$ of the students' prefer public transport. Bursa Uludag University's distance from the city centre makes it difficult to reach the campus by bicycle. Furthermore, the starting of the city metro line from campus helps to explain the height of this number. It should also be remembered that the majority of the participants come from the middle and lower-middle income families. There is often one car in these families and the cost of driving can reach the amounts that students cannot afford with their allowance. The ratio of the students who indicate their preferred transportation as public transport varies from $64 \%$ to $87 \%$ (Isildar and Yildirim, 2008; Muderrisoglu and Altanlar, 2011; Oguz et al., 2011) in the literature.

The statements of the questionnaire that examined the students' behavioural patterns shown that their environmental behaviour was changed depending on the situation they are in.; Their economic situation and the existing opportunities could also affect how they behave. It is possible to claim that their overall behaviour is on the positive side considering the level of knowledge they have and the attitudes they maintain.

\section{Conclusions}

Increasing environmental problems have resulted in an increase in the research carried out on the subject matter. The aim of the research was to identify the causes of these problems and to solve them. Literature is dominated by the studies that examine students' attitudes and behaviour towards environmental issues and environmental problems at almost every level, ranging from primary school to university.

While research in developed countries focuses on how to solve them and how to prevent future problems, research in developing countries is more about understanding the causes of problems. Especially, studies toward university students have a significant share in the current research. This interest emphasizes that university students are leaders who will manage the future. Studies examining the environmental attitudes and behaviour of university students have exposed many contradictions and have laid the foundation for new research. This research, while analysing survey questions, attempted to include findings and contrasts revealed in the previous research in the context of Bursa Uludag University.

It has been observed that gender is not significant on students' environmental awareness. The research found that students belong to the lowest income level $(\$<294)$ differ from all other income levels in their awareness and display lower level environmental awareness. Other income levels did not appear to be a predictive factor of environmental behaviour. As the level of education of the mother increased, the students' environmental awareness increased, but when the mother's education reached the university level, the difference was not significant. Mother occupation too was significant on the student's environmental attitude; students whose mothers were a white collar and self-employed showed higher environmental awareness. In contrast, students who had blue-collars and self-employed fathers achieved higher environmental awareness. Students with farmer fathers scored the lowest awareness. 
Fathers' education not reveals any significance. Finally, Medical and Business School students displayed higher levels of awareness while the School of Agriculture students scored the lowest means.

Most of the students in the research were unable to describe the environment and environmental pollution. This may be the result of them not receiving adequate environmental education up until the university. The students stated that the country's biggest problem was urbanisation. This was followed by air and water pollution. Faculty of Agriculture students do not consider soil pollution as an important problem is one of the remarkable findings of the research.

Another important finding was that the students find a lack of punishment and sanction the most important reason for the lack of sensitivity to the environment in society. On the one hand, it is striking that education about the environment students receive before they come to university is not sufficient. While on the other hand, the ratio of those who stated that the cause of environmental insensitivity in society is lack of education remains at $2.8 \%$. Although students emphasize the lack of knowledge, they want to increase penal sanctions instead of making environmental education more accessible and effective.

As in other studies, Bursa Uludag University students stated that those who make the most contributions to the environment are voluntary organisations. The $2.8 \%$ share of 'education and research of universities' in the environment protection rate is directly proportional to the 75\% 'no' answer to the statement of whether universities are doing their part about the environment. These findings should be very concern rising for the university. Students indicate that they want to take part in the environmental decisionmaking mechanisms of the University. They claim that society should play a more effective role in environmental protection. Another important finding of the study is that students did not see the problem of urbanisation as one of the tasks of society although they ranked this as the most important problem for the country.

In the section that examines the attitudes and behaviours' of the students. it was seen that students adopted the highest behaviour in the society, such as preferring public transportation, using the papers in two sides, separating the garbage on disposal. However, it was observed that one of every three students abstained in behaviour such as using recycled packaging, buying products that do not damage the ozone layer, taking active duties as members of the related institutions and warning the environment polluters. Therefore, the answers that are given suggest that students are inclined to social desirability bias. Or as this result has been underlined by other researchers, it can be interpreted that students do not reflect this to their behaviour even though they have a positive attitude towards the environment.

Acknowledgements. We would like to thank Emeritus Professor Derek J. Clements-Croome for his proofreading, suggestions and feedback during the preparation of the manuscript.

\section{REFERENCES}

[1] Abbas, M. Y., Singh, R. (2014): A survey of environmental awareness, attitude and participation amongst university students: A case study. - International Journal of Science and Research (IJSR) 3(5): 1755-1760. 
[2] Abdulrab, A. H. M. (2015): Effectiveness of kwl-plus strategy on acquisition the concepts in science and attitude towards science for eighth-grade students. - International Journal of Innovative Research and Studies 4(3).

[3] AlMenhali, E. A., Khalid, K., Iyanna, S. (2018): Testing the psychometric properties of the Environmental Attitudes Inventory on undergraduate students in the Arab context: A testretest approach. - PLoS One 13(5): e0195250.

[4] Altin, M., Bacanli, H., Yildiz, K. (2002): Biology teacher candidates' attitudes towards the environment. - V. National Science and Mathematics Education Congress, 16-18 September 2002, Ankara.

[5] Anonymous (2018): Turkey's number of students exceeds 143 countries. - Posta. EJournal. 18 October. https://www.posta.com.tr/turkiyenin-ogrenci-sayisi-143-ulkeninnufusunu-gecti-2051026. Accessed: 1.12.2018.

[6] Arbuthnott, K. D. (2009): Education for sustainable development beyond attitude change. - International Journal of Sustainability in Higher Education 10(2): 152-163.

[7] Artun, H., Uzunoz, A., Akbas, Y. (2013): The evaluation of the factors affecting the levels of environmental literacy of social science prospective teachers. - Pamukkale University Journal of Education 34(2): 1-14.

[8] Arunkumar, J. (2012): A study on assessment of environmental awareness among teacher trainees in teacher training institutes. - International Journal of Research in Social Sciences 2(3): 312-321.

[9] Asunta, T. (2004): Knowledge Sources, Attitudes and Self-Reported Behavior of Secondary-Level Science Students Concerning Environmental Topics. - In: Laine, A., Lavonen, J., Meisalo, V. (eds.) Current Research on Mathematics and Science Education. University of Helsinki Research Report, Helsinki.

[10] Aydin, F., Cepni, O. (2010): University students' attitudes towards environmental problems: A case study from Turkey. - International Journal of the Physical Sciences 5(17): 2715-2720.

[11] Baki, B., Cengiz, E. (2002): Total quality environment management. - Uludag University Journal of Faculty of Economics and Administrative Sciences 11(1): 153-175.

[12] Berberoglu, G., Tosunoglu, C. (1995): Exploratory and confirmatory factor analyses of an environmental attitude scale (EAS) for Turkish university students. - The Journal of Environmental Education 26: 40-44.

[13] Benton, R. (1994): Environmental knowledge and attitudes of undergraduate business students compared to non-business students - Business \& Society 33(2): 191-211.

[14] Benton, R. Jr., Funkhouser, G. R. (1994): Environmental attitudes and knowledge: an international comparison among business students. - Journal of Managerial Issues 6(3): 366-381.

[15] Bostancioglu, D., Varol, G., Ozturk, M. (2017): Students attitudes and levels of environmental awareness and investigating the factors affecting them. - Academic Outlook Journal 60: 266-278.

[16] Bowonder, B. (1987): Environmental problems in developing countries. - Progress in Physical Geography: Earth and Environment 11(2): 246-259.

[17] Bozdogan, E., Sahinler, S., Korkmaz, E. (2016): Environmental awareness and attitudes in university students. an example from Hatay (Turkey). - Oxidation Communications 39(1): 661-672.

[18] Bozoglu, M., Bilgic, A., Kilic-Topuz, B., Ardali, Y. (2016): Factors affecting the students' environmental awareness, attitudes and behaviors in Ondokuz Mayis University, Turkey. - Fresenius Environmental Bulletin (25): 1243-1257.

[19] Budak, D. B., Budak, F., Zaimoglu, Z., Kekec, S., Sucu, M. Y. (2005): Behaviour and attitudes of students towards environmental issues at Faculty of Agriculture. - Journal of Applied Sciences 5(7): 1224-1227.

[20] Bursa Uludag University (2018): 2018-2019 Academic Year Student Number. https://www.uludag.edu.tr/oidb/default/konu/697. 
[21] Cabuk, B., Karacaoglu, O. C. (2003): Investigation of university students' environmental sensitivity. - Ankara University Journal of Faculty of Educational Sciences 36(1-2): 189198.

[22] Celen, U., Yildiz, A., Atak, N., Tabak, R. H., Arisoy, M. (2002): Ankara University Medical Education Faculty students' environmental sensitivity and related factors. - The 8th National Public Health Congress, 23-28 September 2002, Diyarbakır, pp. 421-425.

[23] Chen, C. L., Tsai, C. H. (2016): Marine environmental awareness among university students in Taiwan: a potential signal for sustainability of the oceans. - Environmental Education Research 22(7): 958-977.

[24] Chuanhui, Z., Hanwei, Z. (2011): Cultivation of environmental values for university students under strategic background of environmental informationization. - Energy Procedia 5: 945-951.

[25] Corcoran, P. B, Wals, A. E. J. (eds.) (2004): Higher Education and the Challenge of Sustainability: Problematics, Promise and Practice. - Kluwer Academic Publishers, Dordrecht.

[26] Côrtes, P. L., Dias, A. G., da Silva, T. E. M. E., Pamplona, J. M. V. (2016): Environmental behavior: A comparative study between Brazilian and Portuguese students. - Ambiente e Sociedade 19(3): 111-134.

[27] Crumpei, I., Boncu, S., Crumpei, G. (2014): Environmental attitudes and ecological moral reasoning in Romanian students. - Procedia Social and Behavioral Sciences 114: 461-465.

[28] de La Vega, E. L. (2006): A Preliminary evaluation of awareness, knowledge and attitude in environmental education specialists. Instructors, students and parents in Southwest Florida. - Florida Scientist 69(2): 166-178 (Charlotte Harbor NEP Special Issue of Florida Scientist: Lessons Learned from Transferring Science to Watershed Management).

[29] Demeskhant, N. (2013): Environmental awareness of the students of agricultural universities in Poland and Ukraine. - Journal of Educational Sciences of western Anatolia (BAED), Dokuz Eylul University Institute of Educational Sciences 4(7): 63-68.

[30] Dohrenwend, B. S. (1965): Some effects of open and closed questions on respondents' awareness. - Human Organization 24: 175-184.

[31] Duman-Yuksel, U., Ozkazanc, S. (2015): Investigation of the environmental attitudes and approaches of university students. - 7th World Conference on Educational Sciences. (WCES-015), 05-07 February, Procedia Social and Behavioral Sciences 197: 2191-2200.

[32] Eisenlohr, T., Pfister, M., Balderer, W. (1995): Environmental isotope study and 2-D modelling of cold and thermal karst within the Gemlik (Bursa) area of northwestern Turkey. - Abstracts of the International Symposium and Field Seminar on Karst Waters and Environmental Impacts, 10-20 September 1995, Beldibi, Antalya, Turkey.

[33] Ejem, L. A., Bello, A. Q. (2013): Environmental awareness, literacy and biodiversity conservation practices of freshmen students in Bukidnon State University, Philippines. JPAIR Institutional Research, 1(1): 65-81.

[34] Ek, H. N., Kilic, N., Ogdum, P., Duzgun, G., Seker, S. (2009): First and senior class Adnan Menderes University student's attitudes towards environmental problems. Kastamonu Education Journal 17(1): 125-136.

[35] Elder, J. L. (2003): A Field Guide to Environmental Literacy: Making Strategic Investments in Environmental Education. - Environmental Education Coalition, Rock Spring.

[36] Elsawahli, H. M. H., Mohit, M. A. (2010): Recycling Awareness among Undergraduate Student under KAED Environmental Education: A Case Study of KAED's Students Recycling Behaviour. - ICBEDC USM, Penang.

[37] Erdal, H., Erdal, G., Yucel, M. (2013): Environmental awareness research for university students: case of Gaziosmanpasa University. - Gaziosmanpasa Journal of Scientific Research 4: 57-65. 
[38] Ermolaeva, P. (2010): College students' green culture: Reflecting on the ideal types of environmental awareness and behavior practices. - R\&R Research and Discussion 3(3): 49-74.

[39] Erol, G. H., Gezer, K. (2006): The investigation of candidate teachers: attitudes towards environment. - International Journal of Environmental and Science Education 1(1): 65 77.

[40] Fisher, R. J. (1993): Social desirability bias and the validity of indirect questioning. Journal of Consumer Research 20(2): 303-315.

[41] Foddy, W. (1993): Constructing Questions for Interviews and Questionnaires. Theory and Practice in Social Research. - Cambridge University Press, Cambridge.

[42] Frank, J. D., Meyer, W. J. (2007): University expansion and the knowledge society. Theory and Society 36(4): 287-311.

[43] Gayford, C. (2002): Controversial environmental issues: a case study for the professional development of science teachers. - International Journal of Science Education 24(11): 1191-1200.

[44] Genc, M, Genc, T. (2013): The investigation of candidate teachers' attitudes towards environment. - Asian Journal of Instruction 1(1): 9-19.

[45] Gercek, C. (2016): University students perceptions about environmental ethics. Electronic Journal of Social Sciences 15(59): 1100-1107.

[46] Goldman, D., Yavetz, B., Pe'er, S (2006): Environmental literacy in teacher training in Israel: environmental behavior of new students. - The Journal of Environmental Education 38(1): 3-22.

[47] OECD (2017): Green Growth Indicators 2017. OECD Green Growth Studies. - OECD Publishing, Paris.

[48] Grodzinska-Jurczak, M., Trabula, M. (2001): Ecological awareness of nature teachers in Poland. - Environ Sci and Pollution Research 8(1): 5-6.

[49] Gulgun, B., Onder, S., Aktas, E., Unal-Ankaya, F. (2008): Responses of university students related to environmental problems: a case study of Ege University (IzmirTurkey). - J. Int. Environmental Application and Science 3(4): 234-246.

[50] Hadlock, T. D., Beckwith, J. A. (2002): Recommendations to improve recovery of endangered species in the United States. - Human Dimensions of Wildlife 7: 37-53.

[51] Hartmann, P., Apaolaza-Ibáñez, V. (2012): Consumer attitude and purchase intention toward green energy brands: the roles of psychological benefits and environmental concern. - Journal of Business Research 65(9): 1254-1263.

[52] Hassan, A., Norshariani, A. R., Abdullah, S. I. S. S. (2011): The Level of Environmental Knowledge, Awareness, Attitudes and Practices among UKM Students. - University Kebangsaan, Malaysia.

[53] Heyl, M., Díaz, M. E., Cifuentes, L. (2013): Environmental attitudes and behaviors of college students: a case study conducted at a Chilean University. - Revista Latinoamericana de Psicología 45(3): 489-502.

[54] Higher Education Council (2018): Number of Students by Universities. - Higher Education Council, Ankara. https://istatistik.yok.gov.tr/.

[55] Huang, P. S., Shih, L. H. (2009): Effective environmental management through environmental knowledge management. - Int. J. Environ. Sci. Technol. 6: 35-50.

[56] Isildar, G. Y., Yildirim, F. (2008): The effectiveness of environmental education on environmentally sensitive behaviour. - Education and Science 33(48): 13-27.

[57] Kabera, T. (2017): Environmental impact assessment in higher education institutions in East Africa: the case of Rwanda. - Environ. Sci. Pollut. Res. 24: 7852-7864.

[58] Kagawa, F. (2007): Dissonance in students' perceptions of sustainable development and sustainability: implications for curriculum change. - International Journal of Sustainability in Higher Education 8(3): 317-338.

[59] Kanbak, A. (2015): Environmental attitudes and behaviors of college students: a case study conducted at a Kocaeli University. - KOSBED 30: 77-90. 
[60] Kaplowitz, M., Levine, R. (2005): How environmental knowledge measures up at a big ten university. - Environmental Education Research 11(2): 143-160.

[61] Kasma-Ronkainen, L., Virokannas, H. (1996): Concern about the environment among medical students. - Scand. J. Soc. Med. 24: 121.

[62] Kayali, H. (2010): Social studiesi Turkish and classroom teacher candidates attitudes towards environmental issue. - Marmara Geographical Rev. 21(13): 258-268 (in Turkish).

[63] Kilbourne, W. E., Polonsky, M. J. (2005): Environmental attitudes and their relation to the dominant social paradigm among university students in New Zealand and Australia. Australasian Marketing Journal 13(2): 37-48.

[64] Kiper, T. (2014): Determination of environmental attitudes of students of landscape architecture. - Journal of Tekirdag Agricultural Faculty 11(2): 80-88.

[65] Kollmuss, A., Agyeman, J. (2002): Mind the gap: Why do people act environmentally and what are the barriers to pro-environmental behavior? - Environmental Education Research 8(3): 239-260.

[66] Kolomuc, A., Acigli, S. (2013): A comparison of the attitudes of prospective science teachers and prospective social teacher towards the environment. - International Journal of Social Science 6(7): 687-696.

[67] Korkmaz, M. (2018): Public awareness and perceptions of climate change in concern of climate: Differences in concerns about climate change in the West Mediterranean region of Turkey. - Applied Ecology and Environmental Research 16(4): 4039-4050.

[68] Kormos, C., Gifford, R. (2014): The validity of self-report measures of pro environmental behavior: a meta-analytic review. - J. Environ. Psychol. 40: 359-371

[69] Kose, S., Gencer, A. S., Gezer, K., Erol, G. H., Bilen, K. (2011): Investigation of undergraduate students' environmental attitudes. - International Electronic Journal of Environmental Education 1(2): 85-96.

[70] Kulozu, N. (2016): Youths perception and knowledge towards environmental problems in a developing country in the case of Ataturk University Turkey. - Environmental Science and Pollution Research 1614-7499.

[71] Lee, E. B. (2008): Environmental attitudes and information sources among African American College students. - Reports and Research 40: 29-42.

[72] Lehman, P. H., Geller, E. S. (2004): Behavior analysis and environmental protection: Accomplishments and potential for more. - Behavior and Social Issues 13: 13-32.

[73] Levine, D. S., Strube, M. J. (2012): Environmental attitudes, knowledge, intentions and behaviors among college students. - The Journal of Social Psychology 152: 308-26.

[74] Lozano, R. (2006): Incorporation and institutionalisation of SD into universities: breaking through barriers to change. - Journal of Cleaner Production 14: 787-796.

[75] Lukman, R., Lozano, R., Vamberger, T., Krajnc, M. (2013): Addressing the attitudinal gap towards improving the environment: a case study from a primary school in Slovenia. - Journal of Cleaner Production 48: 93-100.

[76] Major, L, Namestovski, Z, Horak, R., Bagany, A., Pinter-Krekic, V. (2017): Teach it to sustain it! Environmental attitudes of Hungarian teacher training students in Serbia Journal of Cleaner Production 154: 255-268.

[77] Markowitz, E. M., Goldberg, L. R., Ashton, M. C., Lee, K. (2012): Profiling the proenvironmental individual: a personality perspective. - Journal of Personality 80(1): 81-111.

[78] Mazi, F., Demirci, M. (2004): Factors Affecting Biodiversity Reduction and Its Consequences. - In: Marin, M. C., Yildirim, U. (eds.) Contemporary Approaches to Environmental Problems: Ecological, Economic, Political and Managerial Perspectives. Beta Publishing, Istanbul, pp.167-186 (in Turkish).

[79] McDaniel, J., Alley, K. D. (2005): Connecting local environmental knowledge and land use practices: A human ecosystem approach to urbanisation in west Georgia. - Urban Ecosystems 8(1): 23-38. 
[80] Meyer, A. (2016): Heterogeneity in the preferences and pro-environmental behavior of college students: the effects of years on campus, demographics and external factors. Journal of Cleaner Production 112: 3451-3463.

[81] Morigi, J., Krebs, L. M. (2012): Social mobilization networks: the Greenpeace informational practices. - Informacao and Sociedade Estudos 22(3): 133-142.

[82] Muderrisoglu, H., Altanlar, A. (2011): Attitudes and behaviors of undergraduate students toward environmental issues. - Int. J. Environ. Sci. Tech. 8(1): 159-168.

[83] Najam, A., Cleveland, C. J. (2003): Energy and sustainable development at global environmental summits; an evolving agenda. - Environment Development and Sustainability (5): 117-138.

[84] National Education Statistics (2018): National Education Statistics 2017-2018 Education Year, Ministry of National Education. http://sgb.meb.gov.tr/www/icerik_goruntule.php?KNO=327.

[85] Nicolaou, I., Conlon, E. (2013): The Integration of Sustainable Development Competencies in Irish Engineering Education: Findings of a Curriculum Content Investigation of Four Engineering Programs. - Engineering Education for Sustainable Development, Cambridge, England.

[86] Oguz, D., Cakici. I,, Kavas, S. (2010): Environmental awareness of university students in Ankara. Turkey. - African Journal of Agricultural Research 5(19): 2629-2636.

[87] Oguz, D., Cakici, I., Kavas, S. (2011): Environmental awareness of students in higher education. - SDU Faculty of Forestry Journal 12: 34-39.

[88] Ozdemir. O., Yildiz, A., Ocaktan, E., Sarisen, O. (2004): Awareness and sensibility levels of medical students. - Journal of Ankara University Faculty of Medicine 57(3): 117 (in Turkish).

[89] Ozden, M. (2008): Environmental awareness and attitudes of student teachers: an empirical research. - International Research in Geographical and Environmental Education 17(1): 40-55.

[90] Ozen, R. A., Ozen, A. (2017): A study of Firat University Faculty of Veterinary students' view on environmental issues. - Kocatepe Veterinary Journal 10(4): 247-255.

[91] Ozmen, D., Cetinkaya, C. A., Nehir, S. (2005): University students' attitudes towards environmental problems. - Taf Preventive Medicine Bulletin 4(6): 330-344.

[92] Paksoy, S., Paksoy, H. M. (2015): A research on determination the environmental sensitivity of university students: the case study of Kilis. - Assam International Refered Journal 2(4): 120-134.

[93] Palabiyik, H., Altunbas, D. (2004): Urban Solid Wastes and Management. - Yildirim, U., Marin, M. C. (eds.) Contemporary Approaches to Environmental Problems. Beta Publishing, Istanbul.

[94] Pan, S. L., Chou, J., Morrison, A. M., Huang, W. S., Lin, M. C. (2018): Will the future be greener? the environmental behavioral intentions of university tourism students. Sustainability 10(3): 634 .

[95] Panth, K. M., Verma, P, Gupta, M. (2015): The role of attitude in environmental awareness of under graduate students. - International Journal of Research in Humanities and Social Studies 2(7): 55-62.

[96] Pe'er, S., Goldman, D., Yavetz, B. (2007): Environmental literacy in teacher training: attitudes, knowledge and environmental behavior of beginning students. - The Journal of Environmental Education 39(1): 45-59.

[97] Robinson, M, Crowther, D. (2001): Environmental science literacy in science education, biology \& chemistry majors. - The American Biology Teacher 63(1): 9-14.

[98] Sadik, F., Sadik, S. (2014): A study on environmental knowledge and attitudes of teacher candidates. - Procedia Social and Behavioral Sciences 116: 2379-2385.

[99] Sam, N., Gursakal, S., Sam, R. (2010): Determination of environmental risk and environmental attitudes of university students. - Academic Review International Refereed Journal of Social Sciences 20: 116. 
[100] Sama, E. (2003): Teacher candidates' attitudes toward environmental problems. - Journal of Gazi Educational Faculty 23(29): 99-110.

[101] Schultz, P. W., Gouveia, V. V., Cameron, L. D., Tankha, G., Schmuck, P., Franek, M. (2005): Values and their relationship to environmental concern and conservation behaviour. - Journal of Cross-Cultural Psychology 36: 457-475.

[102] Sever, R., Yalcinkaya, E. (2012): Examining the environmental attitudes of pre-service teachers on primary school teaching. - Marmara Geography Journal July 26: 1-15.

[103] Sharon, T., Wright, A. (2006): Giving "teeth" to an environmental policy: a Delphi study at Dalhousie University. - Journal of Cleaner Production 14: 761-768.

[104] Sharma, N. K. (2014): A study on environmental awareness of college students in relation to sex, rural urban background and academic streams wise. - The Online Journal of New Horizons in Education 4(2): 15-20.

[105] Silveira, J. G. D., Cruz, R. D. C. (2012): Study of information about environmental sustainability that circulate on Orkut: an exploratory study of the topic "What about the river?" - Perspectivas em Ciência da Informação 17(2): 143-157.

[106] Singh, R. (2015): Environmental awareness among undergraduate students in relation to their stream of study and area of residence. - Scholarly Research Journal for Interdisciplinary Studies (SJIF) 5.403: 2830-2845.

[107] Sivek, D. J., Hungerford, H. (1990): Predictors of responsible behavior in members of three Wisconsin conservation organizations. - J. Environ. Educ. 21: 35-40.

[108] Stephan, H., Zelli, F. (2009): The Role of International Organisations in Global Environmental Governance. - In book: The Environment Encyclopedia and Directory. $5^{\text {th }}$ Ed. Routledge, Abingdon, UK.

[109] Stern, P. C. (2000): New environmental theories: toward a coherent theory of environmentally significant behaviour. - Journal of Social Issues 56(3): 407-424.

[110] Sungur, A. S. (2017): Ethical attitudes of undergraduates towards environment. - The Journal of Academic Social Science 5(41): 469-479.

[111] Tabachnick, B. G., Fidell, L. S. (2013): Using Multivariate Statistics. Sixth Ed. Pearson, Boston.

[112] Talay, I., Gunduz, S., Akpinar, N. (2004): On the status of environmental education and awareness of undergraduate students at Ankara University Turkey. - Inter. J. Environ. Pollut. 21(3): 293-308.

[113] Tekin, C., Gunes, G. (2018): Environmental awareness in university students and the affecting factors. - Int J Community Med Public Health 5: 422-429.

[114] Thapa B, Graefe AR, Meyer LA (2005): Moderator and mediator effects of scuba diving specialization on marine-based environmental knowledge-behavior contingency - J. Environ. Educ. 37. 53-67. https://doi.org/10.3200/JOEE.37.1.53-68.

[115] Thompson, S. K. (2012): Estimating Proportions, Ratios, and Subpopulation Means. - In: Balding, D. J. et al. (eds.) Sampling. John Wiley \& Sons, Hoboken, New Jersey, pp. 5766.

[116] Tikka, P. M., Kuitunen, M. T., Tynys, S. M. (2000): Effects of educational background on students' attitudes, activity levels and knowledge concerning the environment. Journal of Environmental Education 31(3): 12-19.

[117] Timur, S., Yilmaz, M. (2011): Determining pre-service science teachers' environmental knowledge levels and examining some variables that affect their environmental knowledge levels. - Gazi University Journal of Education 31(1): 303-320.

[118] Tuncer, G., Tekkaya, C., Sungur, S., Cakiroglu, J., Ertepinar, H., Kaplowitz, M. (2009): Assessing pre-service teachers' environmental literacy in Turkey as a mean to develop teacher education programs. - International Journal of Educational Development 29(4): 426-436.

[119] TurkStat (2017): Population by Age Group and Sex according to Address Based Population Registration System. - Turkish Statistic Institute, Ankara. https://biruni.tuik.gov.tr/bolgeselistatistik/tabloOlustur.do. 
[120] TurkStat (2018a): Population by Age Group and Sex. - Turkish Statistic Institute, Ankara. http://www.turkstat.gov.tr/UstMenu.do?metod=temelist Accessed 12.11.2018.

[121] TurkStat (2018b): Labour Force Statistics - Turkish Statistic Institute http://www.tuik.gov.tr/UstMenu.do?metod=temelist Accessed 12.11.2018.

[122] Ullah, M. O., Hasan, A., Udddin, T. (2013): Environmental awareness and disaster factors in Bangladesh. - JAQM 8(4): 34-42.

[123] Vaizoglu, S., Altintas, H., Temel, F., Ahrabi, A. F., Aydogan, D., Bostanci, S., Duran, A., Kockesen, D., Turan, N., Guler, C. (2005): Evaluation of the environmental consciousness of the students in a Medical Faculty in Ankara. - TAF Pev Med Bull. 4(4): 151.

[124] Vicente-Molina, M. A., Fernandez-Sainz. A., Izagirre-Olaizola, J. (2013): Environmental knowledge and other variables affecting pro-environmental behaviour: Comparison of university students from emerging and advanced countries - Journal of Cleaner Production 61: 130-138.

[125] Vicente-Molina, M. A., Fernandez-Sainz, A., Izagirre-Olaizola, J. (2018): Does gender make a difference in pro-environmental behavior? The case of the Basque Country University students. - Journal of Cleaner Production 176: 89-98.

[126] Waas, T., Verbruggen, A., Wright, T. (2010): University research for sustainable development: definition and characteristics explored. - Journal of Cleaner Production 18: 629-636.

[127] Wang, P., Liu, Q., Qi, Y. (2014): Factors influencing sustainable consumption behaviors: A survey of the rural residents in China. - J. Clean. Prod. 63: 152-165.

[128] Withgott, J., Brennan, S. (2007): Essential Environment: The Science Behind the Stories. 2nd Ed. - Pearson Education, San Francisco.

[129] Wong, K. K. (2003): The environmental awareness of university students in Beijing. China. - Journal of Contemporary China 12(36): 519-536.

[130] World Population Prospects (2017): 2017 Revision of World Population Prospects, United Nations. - https://population.un.org/wpp/DataQuery/.

[131] Wright, T. S. A. (2007): Developing research priorities with a cohort of higher education for sustainability experts. - International Journal of Sustainability in Higher Education 8: 34-43.

[132] Yadav, R., Patha, G. S. (2013): Awareness about environmental issues: a study of female students. - Tenth AIMS International Conference on Management, January 6-9, pp. 2939-2942.

[133] Yavetz, B., Goldman, D., Pe'er, S. (2009): Environmental literacy of pre-service teachers in Israel: a comparison between students at the onset and end of their studies. Environmental Education Research 15(4): 393-415.

[134] Yazici, N., Babalik, A. A. (2016): Determination of environmental awareness of university students: the case of Suleyman Demirel University (SDU). - Environmental Earth Sci. 75: 190.

[135] Yilmaz, I, Morgil, P., Aktug, I., Gobekli, İ. (2002): Knowledge of the secondary school and university students on the environment, environmental concepts and problems and suggestions. - Journal of Hacettepe University Faculty of Education 22(23): 156-162.

[136] Yilmaz, N., Erkal, S. (2016): Determining undergraduate students' environmental awareness and environmental sensitivity. - World Journal of Environmental Research 6(2): 67-74.

[137] Yilmaz, O., Boone, W. J., Anderson, H. O. (2004): Views of elementary and middle school Turkish students toward environmental issues. - International Journal of Science Education 26: 1527-1546.

[138] Zelezny, L. C., Chua, P. P., Aldrich, C. (2000): New ways of thinking about environmentalism: Elaborating on gender differences in environmentalism. - Journal of Social Issues 6(3): 443-457. 
[139] Zilahy, G., Huisingh, D. (2009): The roles of academia in regional sustainability initiatives. - Journal of Cleaner Production 17: 1057-1066.

[140] Zsóka, A., Szerényi, Z. M., Széchy, A., Kocsis, T. (2013): Greening due to environmental education? Environmental knowledge, attitudes, consumer behavior and everyday proenvironmental activities of Hungarian high school and university students. - Journal of Cleaner Production 48: 126-138.

[141] Zuzovsky, R. (2001): Learning outcomes and the educational context of mathematics and science teaching in Israel. - Findings from the Third International Mathematics and Science Study - TIMSS 1999, Ramot Tel Aviv University, Tel Aviv.

\begin{abstract}
APPENDIX
Questionnaire

Gender: $\quad$ Female ( ) Male ( )

Faculty: $\quad$ Education ( ) Arts \&Science ( ) Science \& Life Sciences ( ) Business School ( ) Engineering ( ) Architecture ( ) Medical School ( ) Veterinary ( ) Agriculture ( )

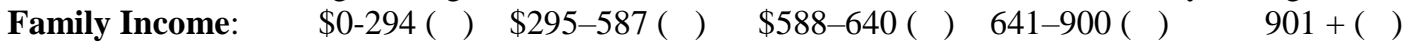

Mothers Education: Literate ( ) Primary Education ( ) Secondary Education ( ) University ( )

Fathers Education: Literate ( ) Primary Education ( ) Secondary Education ( ) University ( )

Mothers Occupation: White-collar ( ) Blue-collar ( ) Self Employed ( ) Housewife ( ) Other ( )

Fathers Occupation: White-collar ( ) Blue-collar ( ) Self Employed ( ) Farmer ( ) Retired ( ) Other ( )
\end{abstract}

Please describe the environment in one sentence.

\title{
What pollution means to you?
}

What is the most important environmental problem in Turkey?

Air pollution ( ) Water Pollution ( ) Soil Pollution ( ) Noise Pollution ( )

Climate Change /Global Warming ( ) Urbanisation ( ) Other:

Are universities susceptible to environmental problems?

Yes ( ) No ( )

What's the reason for not having sensitivity towards environmental problems?

( ) The consequences of environmental problems are not known.

( ) Deterrent punishment/sanctions not issued.

( ) People are aware of environmental problems but they do not act to protect it.

( ) Not enough education and implementation.

( ) Shortage of relevant institutions.

Which organization makes the most important contribution to prevent environmental problems?

( ) Activities of non-governmental organizations. ( ) Works of the municipalities.

( ) Works of the Ministry of Environment and Urbanism. ( ) Public Service Announcements.

( ) Research and educational activities of universities.

What is the role of society in protecting the environment?

( ) To take care not to pollute the environment ( ) To prevent unplanned urbanization

( ) To use environmentally friendly products ( ) To actively take part in preserving the environment Other:

What is the role of universities in protecting the environment?

( ) Environmental education should be compulsory

( ) Students should take part in decision making and application process

( ) More R \& D and training activities should be organized

( ) Should work in cooperation with the industry

( ) Experimental waste should not be randomly disposed

( ) Other:. 
I have taken enough education on the environment at school before the University.

I donate money or become a member of the environment-related organisations.

When purchase. I prefer products with a recycle sign.

I prefer to read in a digital environment instead of printing to avoid paper waste.

I take an active part in protecting the environment.

I take care not to use consumer goods that can damage the ozone layer.

When I see someone polluting the environment I do not remain unresponsive and I warn them.

I dispose of materials such as plastic, glass, paper, battery etc. separately and help them to be recycled.

When I need to use paper. I use them double-sided.

I prefer to use public transport when I'm traveling.

I try to use resources such as electricity, water etc. as efficient as possible.

I make sure that my rubbish goes into the garbage bin.

Our sensitivity to the environment is also our responsibility to society.

I'm aware that environmental pollution is a problem for future generations.

1: Strongly Disagree 2: Disagree 3: No opinion 4: Agree 5: Strongly Agree 